\title{
A Perspective Overview on Hygrophila auriculata
}

\author{
S Dhanalakshmi i,*, N Harikrishnan², N Srinivasan ${ }^{3}$, P Pandian4, BA Tanisha ${ }^{5}$, M Tharun Kumar ${ }^{5}$, V Lokesh ${ }^{5}$, N \\ Yuvashri ${ }^{5}$, S Supriya ${ }^{5}$
}

S Dhanalakshmi ${ }^{1, *}, \mathrm{~N}$

Harikrishnan ${ }^{2}$, N Srinivasan ${ }^{3}$, P

Pandian $^{4}$, BA Tanisha ${ }^{5}$, M Tharun

Kumar $^{5}$, V Lokesh ${ }^{5}$, N Yuvashri ${ }^{5}, \mathrm{~S}$ Supriya ${ }^{5}$

'Department of Pharmacognosy, Faculty of Pharmacy, Dr.M.G.REducational and Research Institute (Deemed to be Univ),Velappanchavadi, Chennai - 600077 , INDIA.

${ }^{2}$ Department of Pharmaceutical Chemistry \& Analysis, Faculty of Pharmacy, Dr.M.G.R

Educational and Research Institute (Deemed to be Univ),Velappanchavadi, Chennai - 600 077, INDIA.

${ }^{3}$ Department of Pharmacy, Faculty of Engineering and Technology, Annamalai University, Annamalai Nagar, Chidambaram INDIA.

${ }^{4}$ Department of Pharmacognosy, Faculty of Engineering and Technology, Annamalai University, Annamalai Nagar, Chidambaram INDIA.

${ }^{5}$ Pharma buddy, Faculty of Pharmacy, Dr.M.G.R Educational and Research Institute (Deemed to be Univ), Velappanchavadi, Chennai - 600077 , INDIA.

\section{Correspondence}

\section{S Dhanalakshmi}

Department of Pharmacognosy, Faculty of Pharmacy, Dr.M.G.R Educational and Research Institute (Deemed to be Univ), Velappanchavadi, Chennai - 600077 , INDIA.

E-mail: dhanadinesh2011@gmail.com

History

- Submission Date: 10-05-2020;

- Review completed: 12-06-2020;

- Accepted Date: 20-06-2020

DOI : 10.5530/pj.2020.12.237

Article Available online http://www.phcogj.com/v12/i6s

\section{Copyright}

(C) 2020 Phcogj.Com. This is an openaccess article distributed under the terms of the Creative Commons Attribution 4.0 International license.

\begin{abstract}
Hygrophila auriculata, belonging to the family Acanthaceae, is a promising medicinal plant with great economic potential. The medicinal value of $H$. auriculata has been appreciated in the ancient medical literature. The plant contains terpenoids, alkaloids, flavonoids, and is traditionally known as an aphrodisiac, renal tonic, and for its health-promoting properties. The plant is cultivated throughout India. However, systematic information on the different aspects of this species is not available. In this review, an attempt has been made to present this information.

Key words: Hygrophila auriculata, Phytochemistry, Pharmacological activity.
\end{abstract}

\section{INTRODUCTION}

Hygrophila auriculata (Schumach.) Heine belongs to family Acanthaceae found in India. It is distributed in tropical and subtropical region in india in literature. The plant is used in cancer and tubercular fistula (Root and seeds used as tonic, for asthama and dysentery. ${ }^{1}$ The leaf, root and seed of this plant are traditionally used for the treatment of inflammation, jaundice, hepatic obstruction, urinary infection, oedema, gout, diabetes, bacterial infection etc. ${ }^{2}$

\section{VERNACULAR NAME ${ }^{3}$}

Marathi: Kolshinda, Talimkhana, Sanskrit: Kokilaksa, Bengali: Kuliyakhara,Gujrati: EkharoHindi: Talmakhana Kannada: Kolavali, Marathi: Talikhana, Kalsunda Tamil: Golmidi, Urdu: Talmakhana.

\section{DESCRIPTION ${ }^{4}$}

Herbs, 40-100 cm tall with unbranched, subquadrangular stems with numerous fasciculate, swollen node, hispid with long hairs. Leavessubsessile, lanceolate, $6-15 \times 1.5-3 \mathrm{~cm}$, acute, hairy, in whorls of 6 at each node, the two outer one smuch larger than the four inner ones. Thorns from the axils of leaves sharp, 2-3 cm long, yellowishbrown. Flowers in axillary clusters of eight at each node in 4 pairs. Bractslanceolate, hairy and ciliate, like the leaves; bracteoleslinear-lanceolate, 1.5-2 $\mathrm{cm}$ long, with hyaline margins in the lowerpart, hairyand ciliate with long white hairs. Calyx 4 partite; upper sepals broader unequal, longer than the other three, all linear lanceolate, 1.2-2 $\mathrm{cm}$ long,with hairy on the back and hyaline ciliate margin. Corolla purple-blue, $2-3 \mathrm{~cm}$ long, bilipped; tube 11-13 $\mathrm{mm}$ long, swollen at top; stamens didynamous 4; filaments glabrous. Ovary 2 celled with 4 ovule, capsuleslinear-oblong, 4 seeded 5-7 $\mathrm{mm}$ long, pointed. Seeds, ovate, compressed, hairy, hygroscopic,black.

\section{PHYTOCHEMISTRY}

Phytochemically, the whole plant contains phytosterols, tannins, carbohydrates, flavonoids, terpenoids, and sterols. Phalnikar et al, analyzed the oil from the seeds and reported the presence of uronic, palmitic, stearic, oleic, and linoleic acids.Apigenin-7-O-glucuronide and apigenin7 -oglucoside were isolated from the flowers and lupeol, betulin, and stigmasterol were isolated from the plant. Alkaloids, steroids, tannins, proteins, flavonoids, carbohydrates, fats, and oils were isolated from the roots. Moreover, the leaves show the presence of alkaloids, carbohydrates, proteins, steroids, glycosides, flavonoids, tannins, phenolic compounds, fats, and oils. ${ }^{4}$

The high-performance thin layer chromatography analysis revealed the presence of phytosterols, namely, $\beta$-sitosterol and lupeol. Maximum content of lupeol was found in the roots $(0.25 \%)$, whereas the maximum content of $\beta$-sitosterol was found in the leaves $(0.069 \%)$ of Asteracantha longifolia. Other isolated chemical constituents include betulin, 25-oxo-hentriacontanyl acetate, and methyl8- $n$ hexyltetracosanoate. ${ }^{5}$

\section{CONCLUSION}

In this systematic review, the pharmacologic studies conducted on $H$. auriculata indicate the immense potential of this plant in the treatment of conditions, such as diarrhea; inflammatory ailments, including liver and kidney disorders, as well as microbial and bacterial infections; cancer, and others. Regarding the plant, the studies indicate that this has an important antioxidant activity due to the presence of water-soluble compounds with potent free radicalscavenging effects, such as flavonoids, terpenoids, alkaloids, steroids, tannins that may be associated with the lower incidence and lower mortality rates of degenerative diseases in human. In spite of all these activities, a major work has been carried out on the chemical, biochemical, pharmaceutic, 

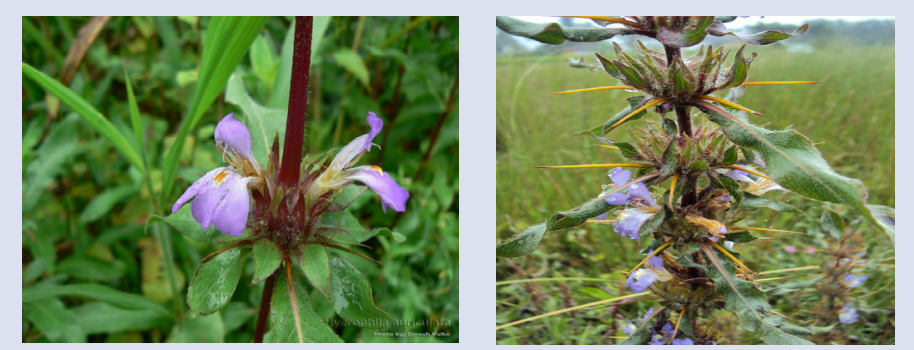

Figure 1: Entire Plant of Hygrophila auriculata (Schumach.).

$$
\begin{aligned}
& \stackrel{\mathrm{O}}{\mathrm{Me}-}\left(\mathrm{CH}_{2}\right)_{15}-\mathrm{CH}-\mathrm{CH}_{2}-\left(\mathrm{CH}_{2}\right)_{4}-\mathrm{CH}_{2}-\mathrm{COOMe} \\
& {\left.\stackrel{(}{\mathrm{C}} \mathrm{H}_{2}\right)_{5}}_{\mathrm{Me}}
\end{aligned}
$$

25-oxo-hentriacontanyl acetate Methyl 8-n-hexyltetracosanoate

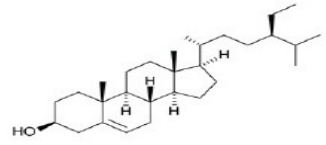

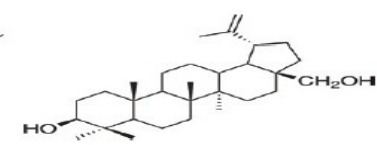

$\beta$-sitosterol Betulin<smiles>C=C(C)C1CCC2(C)CCCC(C3CCC(C)C4CCC(O)C(C)C43)C1CC2</smiles>

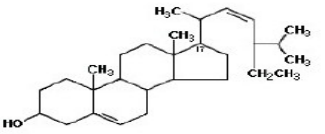

Lupeol Stigmasterol<smiles>CCCCCCCCCCCCCCCCCCCC(=O)O</smiles><smiles>C=C(C)CCCCCCCCCCC</smiles>

Figure 2: Phytochemical present in Hygrophila auriculata (Schumach). ${ }^{5}$

\begin{tabular}{|c|c|c|c|c|c|}
\hline S.No & Title & Journal Name & Vol / Issue / Year & Author & Conclusion \\
\hline 1. & $\begin{array}{c}\text { Preliminary Phytochemical } \\
\text { and Pharmacognostical } \\
\text { Screening of the Ayurvedic } \\
\text { Drug Hygrophila auriculata (K. } \\
\text { Schum) Heine }\end{array}$ & $\begin{array}{c}\text { Pharmacognosy } \\
\text { Journal }\end{array}$ & $\begin{array}{c}\text { Vol 3, } \\
\text { Issue } 23,2013\end{array}$ & $\begin{array}{l}\text { Mohammed } \\
\text { Safaraj etal }\end{array}$ & $\begin{array}{c}\text { Physico-chemical studies revealed } \\
\text { alcohol soluble extractive }(5.12 \% \mathrm{w} / \mathrm{w}) \text {, } \\
\text { water soluble extractive }(24.96) \text {, total ash } \\
(9.90) \text {, acid insoluble ash }(1.48) \text {, water } \\
\text { soluble ash }(8.35 \% \mathrm{w} / \mathrm{w}), \text { loss on drying } \\
(6.30 \% \mathrm{w} / \mathrm{w}) \text {, swelling index }(2.0 \% \mathrm{w} / \mathrm{w}) \text {, } \\
\text { foreign matter }(1.10 \% \mathrm{w} / \mathrm{w})\end{array}$ \\
\hline
\end{tabular}

\section{Table 1: Pharmacognostical Study.}

Table 2: Phytochemical investigation study. The phytochemical investigation of Hygrophila auriculata review strengthen the review of the article. The

\begin{tabular}{|c|c|c|c|c|c|}
\hline S.No & Title & Journal Name & Vol / Issue / Year & Author & Conclusion \\
\hline 2. & $\begin{array}{c}\text { Ethnomedicinal, phytochemical and pharmacological } \\
\text { updates on Hygrophila auriculata (Schum.) Hiene: an } \\
\text { overview }\end{array}$ & $\begin{array}{c}\text { Journal of } \\
\text { Integrative medicine }\end{array}$ & Vol 16, Issue 5, 2012 & Neeraj et al ${ }^{7}$ & $\begin{array}{l}\text { The plant contain } \\
\text { flavonoids } \\
\text { (apigenin, luteolin, } \\
\text { ellagic acid, gallic acid } \\
\text { and quercetin), } \\
\text { alkaloids } \\
\text { (asteracanthine and } \\
\text { asteracanthicine), } \\
\text { triterpenes (lupeol, lupenone, } \\
\text { hentricontane and betulin), sterols }\end{array}$ \\
\hline 3. & $\begin{array}{l}\text { Neuroprotective and antioxidant potential of } \\
\text { terpenoid fraction from Hygrophila auriculata against } \\
\text { transient global cerebral ischemia in rats }\end{array}$ & $\begin{array}{c}\text { Pharmaceutical } \\
\text { Biology }\end{array}$ & Vol 51, Issue 3, 2013 & $\begin{array}{c}\text { Rupesh Kanhere } \\
\text { et } a l^{8}\end{array}$ & $\begin{array}{l}\text { Hygrophila auriculata shows } \\
\text { neuroprotective potential against } \\
\text { tGCI induced oxidative stress. }\end{array}$ \\
\hline 4. & $\begin{array}{l}\text { Studies on phytochemical screening, tannin content } \\
\text { and their antibacterial activity of Hygrophila } \\
\text { auriculata leaf extracts }\end{array}$ & $\begin{array}{l}\text { International journal } \\
\text { of current science }\end{array}$ & $\begin{array}{l}19(4), \\
2016\end{array}$ & Prasanna $\mathrm{M}$ et al ${ }^{9}$ & $\begin{array}{l}\text { The powerful antibacterial effect } \\
\text { is attributed to the greater amount } \\
\text { of tannin compound in the } \\
\text { acetone leaf extract of Hygrophila } \\
\text { auriculata }\end{array}$ \\
\hline
\end{tabular}
phytochemical investigation are listed below: 
Table 3: Pharmacological investigation.

\begin{tabular}{|c|c|c|c|c|c|}
\hline S.No & Title & Journal Name & Vol / Issue / Year & Author & Conclusion \\
\hline 5. & $\begin{array}{c}\text { Preliminary studies on diuretic effect } \\
\text { of Hygrophila auriculata (schum) heine } \\
\text { in rats }\end{array}$ & $\begin{array}{l}\text { International Journal } \\
\text { of Health Research }\end{array}$ & Vol 2, Issue 1, 2009 & S.Hussain et al $^{10}$ & $\begin{array}{l}\text { diuresis induced by the } \mathrm{n} \text {-butanol fraction } \\
\text { was almost similar to that produced by the } \\
\text { frusemide. }\end{array}$ \\
\hline 6. & $\begin{array}{l}\text { Action of Hygrophila auriculata against } \\
\text { streptozotocin-induced oxidative stress }\end{array}$ & $\begin{array}{l}\text { Journal of Ethnopharm } \\
\text { acology }\end{array}$ & Vol 104, Issue 3 & M. vijayakumar et a $1^{1 l}$ & $\begin{array}{c}\text { Aerial parts of Hygrophila auriculata extract } \\
\text { (HAEt, } 100 \text { and } 250 \mathrm{mg} / \mathrm{kg} \text { body weight) } \\
\text { for } 3 \text { weeks showed significant reduction in } \\
\text { blood glucose, }\end{array}$ \\
\hline 7. & $\begin{array}{c}\text { Anti-endotoxin effects of terpenoids } \\
\text { fraction from Hygrophila auriculata } \\
\text { in lipopolysaccharide-induced septic } \\
\text { shock in rats }\end{array}$ & Pharmaceutical biology & $\begin{array}{l}\text { Vol 54, Issue 4, } \\
2016\end{array}$ & $\begin{array}{l}\text { Safarajan hussain } \\
\text { et } a l^{12}\end{array}$ & $\begin{array}{c}\text { Terpenoid fraction (TF) from alcohol (70\%) } \\
\text { extract of the whole plant of Hygrophila } \\
\text { auriculata and assess its anti-inflammatory } \\
\text { activity. }\end{array}$ \\
\hline 8. & $\begin{array}{l}\text { Phytochemical screening, anti-oxidant } \\
\text { activity and in vitro anti-diabetic } \\
\text { activity of aqueous, methanolic, } \\
\text { ethanolic and chloroformic extracts of } \\
\text { Hygrophila auriculata }\end{array}$ & $\begin{array}{l}\text { International journal } \\
\text { of pharmacy and } \\
\text { pharmaceutical } \\
\text { Science }\end{array}$ & Vol 6, issue 5, 2014 & Archit rastogi et $a l^{13}$ & $\begin{array}{l}\text { The methanolic extract contained the } \\
\text { maximum number of phytochemicals. } \\
\text { The antioxidant activity, alpha amylase } \\
\text { inhibition and glucose diffusion inhibition } \\
\text { were all found to be high. }\end{array}$ \\
\hline 9. & $\begin{array}{l}\text { Protective effect of ethanolic extract } \\
\text { of Hygrophila auriculata seeds in } \\
\text { cyproterone acetate-induced sexual } \\
\text { dysfunction in male albino rats }\end{array}$ & Andrologia & 9,2019 & Chaitali Ghosh et al ${ }^{14}$ & $\begin{array}{l}\text { H. auriculata has androgenic and } \\
\text { antioxidant properties that can improve } \\
\text { male infertility without metabolic toxicity. }\end{array}$ \\
\hline 10. & $\begin{array}{c}\text { Experimental evaluation of Hygrophila } \\
\text { Schulli seed extracts for antistress activ- } \\
\text { ity }\end{array}$ & Ancient science of life & $\begin{array}{l}\text { Vol 37, Issue 1, } \\
2017\end{array}$ & $\begin{array}{l}\text { Dayanandh Kannur } \\
\text { et } a l^{15}\end{array}$ & $\begin{array}{l}\text { HPLC analysis confirmed the presence } \\
\text { of flavonoid Quercetin, the ethanolic and } \\
\text { hexane extracts were found to increase the } \\
\text { swim endurance time, both extracts lowered } \\
\text { the elevated blood glucose, cholesterol } \\
\text { as well as triglyceride levels in cold } \\
\text { immobilization stress. }\end{array}$ \\
\hline 11. & $\begin{array}{l}\text { Hygrophila auriculata (K. Schum) } \\
\text { Heine: Ethnobotany, Phytochemistry } \\
\text { and pharmacology }\end{array}$ & $\begin{array}{l}\text { Asian journal of } \\
\text { traditional medicine }\end{array}$ & Vol 5, Issue 4,2010 & Sheeba et al ${ }^{16}$ & $\begin{array}{l}\text { Ethanobotanical and traditional uses as } \\
\text { well as phytochemical and pharmacological } \\
\text { reports about Hygrophila auriculata. }\end{array}$ \\
\hline
\end{tabular}

Figure 4: Biotechnological investigation.

\begin{tabular}{|c|c|c|c|c|c|}
\hline S.No & Title & Journal Name & Vol / Issue / Year & Author & Conclusion \\
\hline 12. & $\begin{array}{l}\text { Elemental analysis of some } \\
\text { ethnomedicinaly important } \\
\text { hydrophytes and marsh } \\
\text { plants of India used in } \\
\text { traditional medicine }\end{array}$ & Asian Pacific & Vol 2, issue 3, 2012 & Somnath et $a l^{17}$ & $\begin{array}{l}\text { Total of } 11 \text { elements } \mathrm{K}^{+}, \\
\mathrm{Mg}^{+2}, \mathrm{Ca}^{+2}, \mathrm{Na}^{+}, \mathrm{Fe}^{+2}, \mathrm{Mn}^{+2}, \\
\mathrm{Cu}^{+3}, \mathrm{Mn}^{+2}, \mathrm{Cu}^{+3}, \mathrm{Cr}^{+3}, \\
\mathrm{Zn}^{+2}, \mathrm{~Pb}^{+4} \text { and } \mathrm{Cd}^{+2} \text { have } \\
\text { been measured by Atomic } \\
\text { absorption method. }\end{array}$ \\
\hline
\end{tabular}

and pharmacologic aspects of the plant and hence, an extensive investigation, especially on its clinical efficacy is needed to exploit its therapeutic utility to combat diseases. As the global interest toward traditional medicines over the conventional treatment is increasing, due to safe and well-tolerated remedies provided by them for the chronic illness with lesser side effects, this review targets $H$. spinosa as a potentially safe and effective plant that has important medicinal values and benefits.

\section{REFERENCES}

1. Sudeshna saha. Potential of Hygrophila auriculata (Schumach.) Heine as a source of future anti-cancer drugs: A comprehensive review, Journal of Pharmacognosy and Phytochemistry. Volume-6, Issue-4,2017:1725-1740.

2. Sarfaraj Hussain. Hygrophila auriculata (K. Schum) Heine: Ethnobotany, phytochemistry and pharmacology., Asian journal of Traditional Medicine., Vol5, Issue 4, 2010:122-4.

3. Duke James A. Phytochemical and Ethenobotanical Database, by Dr. Jim duke of ARS /USDA (online)

4. Khandelwal KR. Practical Pharmacognosy.Nirali Prakashan. New Delhi, 2004;11 Edn:184.

5. Nadkarni KM. Indian Materia Medica". Popular Prakashan, Bombay, 1978.
6. Mohammed Safaraj. Preliminary Phytochemical and Pharmacognostical Screening of the Ayurvedic Drug Hygrophila auriculata (K. Schum) Heine, Pharmacognosy Journal, Vol 3, Issue 23, 2013 pg.no: 225-32.

7. Neeraj. Ethnomedicinal, phytochemical and pharmacological updates on Hygrophila auriculata (Schum.) Hiene: an overview, Journal of Integrative medicine, Vol 16, Issue 5, 2012, pg.no: 665-71.

8. Rupesh Kanhere. Neuroprotective and antioxidant potential of terpenoid fraction from Hygrophila auriculata against transient global cerebral ischemia in rats, Journal of Integrative medicine. Vol 51, Issue 3, 2013: 97-103.

9. Prasanna M. Studies on phytochemical screening, tannin content and their antibacterial activity of Hygrophila auriculata leaf extracts, International journal of current science. 19 (4),2016: 112-117.

10. S.Hussain. Preliminary studies on diuretic effect of Hygrophila auriculata (schum) heine in rats, International Journal of Health Research, Vol 2, Issue 1, 2009:56-63.

11. M. vijayakumar, Action of Hygrophila auriculata against streptozotocin-induced oxidative stress, Journal of Ethnopharmacology, Vol 104, Issue3:113-122.

12. Safarajan Hussain. Anti-endotoxin effects of terpenoids fraction from Hygrophila auriculata in lipopolysaccharide-induced septic shock in rats, Pharmaceutical biology, Vol 54, Issue 4,2016: 265-271.

13. Archit Rastogi. Phytochemical screening, anti-oxidant activity and in vitro antidiabetic activity of aqueous, methanolic, ethanolic and chloroformic extracts of Hygrophila auriculata, International journal of pharmacy and pharmaceutical Science, Vol 6, issue 5, 2014:451-462. 
14. Chaitali Ghosh. Protective effect of ethanolic extract of Hygrophila auriculata seeds in cyproterone acetate-induced sexual dysfunction in male albino rats, Andrologia, Vol -9, 2019.

15. Dayanandh Kannur. Experimental evaluation of Hygrophila Schulli seed extracts for antistress activity, Ancient science of life, Vol 37, Issue 1,2017:346-351.
16. Sheeba, Hygrophila auriculata (K. Schum) Heine: Ethnobotany, Phytochemistry and pharmacology, Asian journal of traditional medicine, Vol 5, Issue 4,2010:214 221.

17. Somnath. Elemental analysis of some ethnomedicinaly important hydrophytes and marsh plants of India used in traditional medicine,Asian Pacific, Vol 2, issue 3, 2012:184-93.

\section{GRAPHICAL ABSTRACT}

\section{ABOUT AUTHORS}

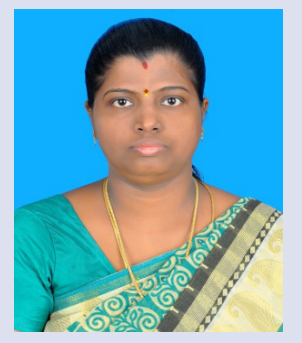

S.Dhanalakshmi, working as Assistant Professor Under Faculty of Pharmacy, Dr.M.G.R Educational and Research Institute,Chennai - 600 077. Her Specialist area of interest is Herbal Formulation and Marine drug development. She received Young Educator and Research Award, on Teachers Day Celebration in the year of 2019. Currently working in the area of Endometrial cancer research by using marine source.

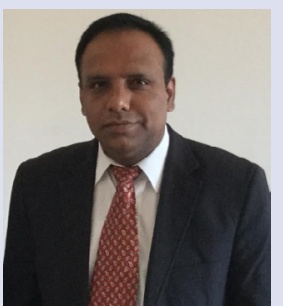

Dr.N.Harikrishnan, working as Principal cum Professor Under Faculty of Pharmacy, Dr.M.G.R Educational and Research Institute,Chennai - 600 077. His Specialist area of interest is Standardisation and Quality control of Formulation and Marine drug development. He received Educational Leadership Award by Dewang Mehta - National Educational Awards, in the year of 2020. Currently working in the thirst area GAD - TLC of research by using marine. 

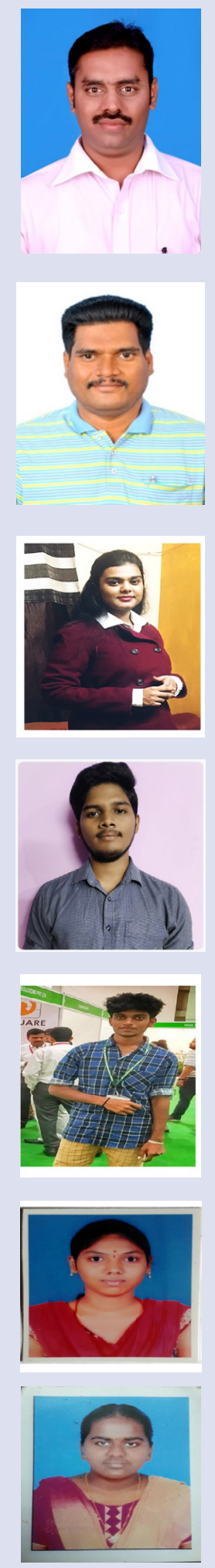

N Srinivasan is currently working as Assistant Professor in Department of Pharmacy, Faculty of Engineering and Technology, Annamalai University, Annamalai Nagar, graduated and post-graduated from The Tamil Nadu Dr. M.G.R Medical university, Chennai and Ph.D from Annamalai University. His research is mainly in the field of Liver protective agents from natural sources. His research attention is isolation of metabolites from medicinal plants and study about its biological properties.

P.Pandian is working as an Associate Professor in the Department of pharmacy, Annamalai University. He received his B.Pharm degree and M.Pharm in industrial pharmacy and his Ph.d in pharmacy from Annamalai University, Annamalai nagar, india in 1999, 2001 and 2016 respectively. His research topic include in Marine pharmacology and Herbal technology.

B.A.Tanisha is Pharma Buddy Under Faculty of Pharmacy, Dr.MGR Educational and Research Institute, Chennai -600 077. Her thrist area of research is under Molecular docking studies, research topic include in Marine pharmacology and Herbal technology.

M.Tharun Kumar is Pharma Buddy Under Faculty of Pharmacy, Dr.MGR Educational and Research Institute, Chennai - 600 077. His thrist area of research is under Molecular docking studies, recently doing research work for biomedical devices.

V.Lokesh is Pharma Buddy Under Faculty of Pharmacy, Dr.MGR Educational and Research Institute, Chennai -600 077. His thrist area of research is under Molecular docking studies.

N.Yuvashri is Pharma Buddy Under Faculty of Pharmacy, Dr.MGR Educational and Research Institute, Chennai -600 077. Her thrist area of research is under Marine research studies, recently doing research work for Pcos Neutraceuticals.

S.Supriya is Pharma Buddy Under Faculty of Pharmacy, Dr.MGR Educational and Research Institute, Chennai - 600 077. Her thrist area of research is under Marines research studies, recently doing research work for herbal formulations.

Cite this article: Dhanalakshmi S, Harikrishnan N, Srinivasan N, Pandian P, Tanisha BA, Kumar MT, et al. A Perspective Overview on Hygrophila auriculate. Pharmacogn J. 2020;12(6)Suppl:1748-52. 